\title{
NÁKUPNÍ PREFERENCE CÍLOVÉHO SEGMENTU NÁVŠTĚVNÍKŮ ZOO JIHLAVA
}

\author{
Stanislava Pachrová, Eva Janoušková, Alice Šedivá Neckářová
}

\begin{abstract}
Zoological gardens are very popular places for spending free time not only for residents, but for visitors of destinations, too. The zoo in Jihlava is one of the best zoos in the Czech Republic and at the same time, it is the most visited tourism attraction not only in the town of Jihlava, but also in the whole Vysocina Region. This article presents results of primary marketing research among 1,200 Jihlava zoo visitors - families with children who were not residents of the town. The research was held by using questionnaires among these visitors in 2018. The main aim of the research was to define a profile of non-residential visitors of the zoo and to describe their current, as well as possible buying behaviour. From the research results it can be e.g. stated that the Zoo Jihlava is attracting mainly Czech families with children, from which more than half arrived just from the Region of Vysocina. With more than $80 \%$ probability children are to the zoo accompanied by their parents. More than half of all children in the zoo were in their pre-school years, most of the rest ones were under 15. It is also interesting that $70 \%$ of non-residential respondents visit the zoo repeatedly.
\end{abstract}

Keywords: marketing research, sustainable tourism, tourism services, zoological garden

\section{Úvod}

Zoologické zahrady jsou oblíbeným místem trávení volného času, a to jak pro místní obyvatele, tak pro návštěvníky destinace. Zoo nejsou typickými podniky cestovního ruchu, nebot' mají i řadu jiných funkcí (např. funkci zachování vzácných a ohrožených druhů organismů, funkci osvětovou a vzdělávací...). Z ekonomického hlediska jsou pro ně důležitou položkou př́ijmy plynoucí z návštěvnosti. Mezi nejnavštěvovanější zoologické zahrady v ČR patří Zoo Jihlava. Jako př́spěvkovou organizaci ji zřizuje Statutární město Jihlava. V roce 2017 dosáhl počet návštěvníků jihlavské zoo bezmála 317000 . V žebřričku padesáti nejnavštěvovanějších turistických cílů Česka zaujímá 27. pozici a je osmou nejnavštěvovanější zoo v ČR (CzechTourism, 2018; Zoo Jihlava, 2018). Významný segment návštěvníků zoo tvoří rodiny s dětmi.

V jihlavské zoo byl na žádost Magistrátu statutárního města Jihlava realizován primární marketingový výzkum, a to na reprezentativním vzorku mimojihlavských návštěvníků zoo. Výzkum byl cílen na rodiny s dětmi a byl 
realizován Katedrou cestovního ruchu Vysoké školy polytechnické Jihlava (dále též VŠPJ). Výsledky výzkumu umožnily definovat aktuální profil mimojihlavského návštěvníka zoo ze segmentu rodin s dětmi, charakterizovaly jeho současné nákupní chování spojené s návštěvou zoologické zahrady i města Jihlavy a popsaly jeho potenciální nákupní chování v případě rozšiřrení nabídky služeb pro rodiny s dětmi př́imo $\mathrm{v}$ zoo, nebo $\mathrm{v}$ její blízkosti. Cílem příspěvku je prezentovat vybrané výsledky tohoto primárního výzkumu realizovaného v roce 2018.

\section{Teoreticko-metodická východiska}

K efektivnímu ř́zení návštěvnosti zoologických zahrad je v současné době nedostačující spoléhat pouze na atraktivitu chovaných živočišných druhů a zajímavě upravené výběhy a jejich okolí, př́ípadně na různé tematické akce. V zostřující se konkurenci je nezbytné jasně definovat preferovaný cílový segment poptávky, což spadá do aktivit strategického marketingu (Kotler, Armstrong, 2001). Cílem je identifikovat homogenní zákaznické skupiny s obdobným chováním a spotřebními zvyklostmi a často i charakteristikami (Kalka, Mäßen, 2003), které budou mít pro daný objekt preferované př́nosy (Stanford, 2014). V př́padě zoologických zahrad jsou preferovanou cílovou skupinou zákazníků především školská zařízení a rodiny s dětmi. Zejména děti jsou tedy velmi početně zastoupenou skupinou zákazníků zoologických zahrad (Knežević, Žučko, Ljuština, 2016).

Na segmentaci navazuje tržní zacílení, tj. zaměření se na jeden preferovaný segment nebo zvolení několika preferovaných segmentů, dalším krokem může být diferenciace (tj. vytvoření marketingového mixu na míru každého zvoleného segmentu), následuje tržní umístění (Kotler, Bowen a Makens, 2014). Velmi důležité je vytvoření profilu návštěvníka, které slouží $\mathrm{k}$ lepšímu pochopení jeho potřeb, přání a požadavků, přičemž profil segmentu je de facto popis ,typického zákazníka" daného segmentu (Jakubíková, 2008). Pro zoologické zahrady, stejně jako pro všechny ostatní subjekty na straně nabídky cestovního ruchu, je v dnešní dynamické době potřeba sledovat přání, preference a požadavky konkrétních zákaznických skupin, zejména těch preferovaných, a také se soustředit na př́padné změny trendů v nákupním a spotřebním chování a včas na ně pružně reagovat.

Výzkumy v zoologických zahradách byly v minulosti realizovány mnohými autory, část výzkumů se zabývá i návštěvností zoologických zahrad, nebo profilem a preferencemi návštěvníků. Profilu návštěvníka zoologických zahrad se rámcově věnuje např́íklad Mason (2010) nebo Knežević, Žučko a Ljuština (2016). Whitword (2012) se ve svém výzkumu zaobíral determinujícími faktory pro návštěvnost zoologických zahrad ve Velké Británii. Luebke a Matiasek (2013) $\mathrm{v}$ rámci studie zkoumali reakce návštěvníků na konkrétní druhy zvírat. Lee (2015) se ve svém výzkum realizovaném ve veřejných zoologických zahradách zabývá 
zákazníkovou spokojeností. Přri výzkumu v zoo je nutné vzít v úvahu skutečnost, že návštěvníci netvoří homogenní skupinu, liší se jejich motivace k návštěvě, která souvisí se vzděláním i sociálními interakcemi s rodinou a přáteli (Knežević, Žučko a Ljuština, 2016). Preferencemi návštěvníků při návštěvě zoologické zahrady se zabývá např. Carr (2016). Phelan, Bauer a Lewalter (2018) se v rámci svého výzkumu zabývali motivací návštěvníkủ zoologických zahrad.

Katedra cestovního ruchu VŠPJ prováděla v Zoo Jihlava marketingové šetření zaměřené na segment rodin s dětmi v období květen až červenec 2018 (cílová skupina respondentů byla definována zadavatelem výzkumu). Sběr primárních dat byl realizován metodou dotazníkového šetření. Dotazník byl vytvořen a distribuován VŠPJ na základě požadavků zadavatele výzkumu. Měl celkem 24 otázek (uzavřené, polouzavřené, škálové). V každém měsíci výzkumu bylo získáno 400 správně a úplně vyplněných dotazníků, celkový výběrový soubor tedy čítá 1200 respondentů. Respondentem mohla být pouze plnoletá osoba, která byla na návštěvě zoologické zahrady $\mathrm{s}$ minimálně jedním dítětem a nebyla rezidentem Jihlavy.

Data byla získána technikou osobního rozhovoru s návštěvníky $\mathrm{v}$ areálu Zoologické zahrady Jihlava, sběr dat byl anonymní. Tazateli byli proškolení studenti VŠPJ, kteří výběr respondentů patřících do požadovaného segmentu trhu (rodin $\mathrm{s}$ dětmi) prováděli náhodně. Data byla sbírána $\mathrm{v}$ různých dnech týdne opakovaně $\mathrm{v}$ různých časových obdobích dní tak, aby se zabránilo zkreslení výsledků výzkumu např. vlivem špatného počasí.

Cílem výzkumu mezi mimojihlavskými návštěvníky Zoologické zahrady Jihlava bylo definovat jejich aktuální profil, vyhodnotit jejich současné nákupní chování a zjistit preference $\mathrm{v}$ jejich budoucím nákupním chování $\mathrm{v}$ případě rozšíření nabídky služeb pro rodiny s dětmi prrímo v zoo, nebo v její blízkosti. Ke splnění cíle bylo při zpracování dat využito matematicko-statistických metod a z vědeckých metod analýzy a syntézy. Data byla zpracována pomocí programů Microsoft Excel a Statistica 13. Všechny tabulky a grafy v tomto prŕíspěvku jsou vlastním dílem autorského kolektivu.

\section{Výsledky výzkumu}

\section{Charakteristika výběrového souboru respondentů}

Z celkového počtu 1200 respondentů bylo 70 \% žen a $30 \%$ mužů. $85 \%$ dotázaných mělo úspěšně ukončeno minimálně středoškolské vzdělání s maturitou (62 \% středoškolské a $23 \%$ vysokoškolské), $15 \%$ mělo ukončeno základní vzdělání, nebo byli vyučeni. S rostoucí vzdělaností účastníků cestovního ruchu roste obvykle jejich náročnost na kvalitu poskytovaných služeb a současně pro opakovanost návštěv vyžadují nové impulzy, např. v podobě inovace služeb pro návštěvníky. 
Z hlediska věkové struktury dospělých návštěvníků Zoologické zahrady Jihlava, kteří na návštěvu zoo přišli s minimálně jedním dítětem, bylo $82 \%$ z celkového počtu dotázaných ve věku 27 - 49 let. Po 7 \% pak bylo návštěvníků ve věku do 26 let a návštěvníků ve věku 50 - 59 let. Nejméně dotazovaných bylo starších 60 let (4 \%).

Z výsledků výzkumu vyplývá, že naprostá většina dospělých, kteří do zoo s dětmi přijdou, jsou př́mo jejich rodiče $(88 \%)$ - viz graf 1 . Tento fakt koresponduje se zjištěnou věkovou strukturou respondentů. Více než desetina dotázaných byla v zoo se svými vnoučaty. Pouhé jedno procento respondentů mělo k doprovázeným dětem jiný vztah, např. byli pouze známí, nebo doprovázeli děti svých sourozenců (např. neteř).

Graf 1: Vztah dospělého respondenta $\mathrm{k}$ doprovázenému dítěti

Graph 1: Relationship between an adult respondent and the accompanied child

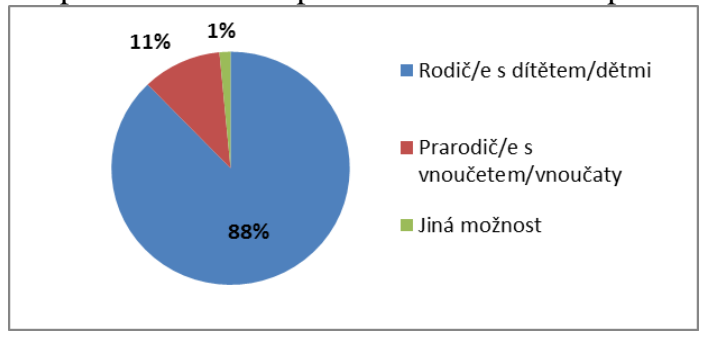

1200 respondentů s sebou do zoo přivedlo celkem 2073 dětí, v průměru je to tedy 1,7 dítěte na 1 dospělého respondenta. Nadpoloviční většina (54\%) doprovázených dětí byla předškolního věku, tj. ve věku 1 - 5 let, $45 \%$ dětí bylo ve věku, kdy navštěvují základní školu (6 - 15 let). Starší 15 let bylo pouze jedno procento dětí.

Důležitým bodem výzkumu bylo zjistit, odkud do Zoo Jihlava návštěvníci $\mathrm{s}$ dětmi přijíždějí. Zahraničních návštěvníků $\mathrm{s}$ dětmi bylo $\mathrm{v}$ rámci výzkumu zachyceno méně než půl procenta $z$ celkového počtu respondentů - tito návštěvníci měli bydliště na Slovensku. Výsledky výzkumu dále prokázaly, že děti do Zoo Jihlava nejčastěji vodí návštěvníci s bydlištěm v rámci Kraje Vysočina - byla jich nadpoloviční většina $\mathrm{z}$ dotazovaných $(53 \%)$, nejvíce $\mathrm{z}$ nich pak přijelo z Humpolce, Třebíče a Pelhřimova. Necelou zbývající polovinu respondentů tvořili návštěvníci z ostatních krajů České republiky - nejvíce z Jihočeského kraje (necelých $10 \% \mathrm{z}$ počtu dotazovaných), dále pak ze Středočeského (7\%), Jihomoravského (6\%) a Pardubického kraje (necelých $6 \%$ ).

V rámci dotazníkového šetření bylo dále zjišs’ováno, zda se návštěvníci do zoo opakovaně vracejí. Loajální a opakovaně se vracející zákazníci jsou cílem každého podniku. V ideálním př́ípadě tito návštěvníci sami podnik dále propagují mezi svými prŕbuznými a známými a díky tomu následně v př́štím období dochází 
k multiplikaci návštěvnosti. Cílem každého podniku cestovního ruchu je tedy zvyšovat jejich podíl. Z celkového počtu 1200 dotázaných jich $30 \%$ bylo v zoo poprvé (graf 2). Pro zoologickou zahradu je to velmi pozitivní zjištění, nebot' to znamená, že $70 \%$ mimojihlavských návštěvníků se do ní vrací, přičemž více než pětina se jich vrací opakovaně.

Graf 2: Opakovanost návštěv Zoo Jihlava mimojihlavskými návštěvníky Graph 2: Repetitiveness of visits to the Jihlava Zoo by non-residential visitors

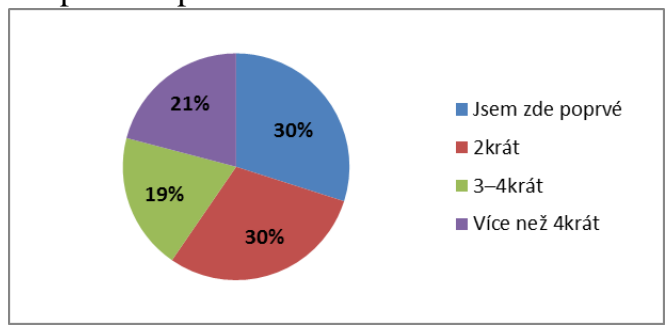

Dále bylo zjištěno, že $62 \%$ respondentů má v plánu se do Zoo Jihlava v průběhu následujících 12 měsíců znovu vrátit. Přibližně čtvrtina dotázaných (24\%) zatím nebyla o opakování návštěvy zoo do roku ode dne dotazování rozhodnuta, $14 \%$ odpovědělo, že se v uvedené době nevrátí. Skupina těch, kteří se pravděpodobně brzy nevrátí, je poměrně velký podíl z celkového množství dotázaných. Důvodem může být nap̌r. to, že rodiny s dětmi se snaží vymýšlet pestrý program pro svůj volný čas, který se neopakuje. Podnětem k opakované návštěvě $\mathrm{v}$ prrípadě těchto návštěvníků by se mohly stát různé tematické akce, o kterých je ovšem potřeba $\mathrm{s}$ dostatečným časovým předstihem potenciální návštěvníky informovat.

Z 1200 respondentů jich 996 (83 \%) přijelo do Jihlavy na jednodenní výlet a neměli $\mathrm{v}$ úmyslu zde přenocovat. Pouze necelá pětina dotázaných ve městě přenocovala, $11 \%$ jich zůstalo na 1 až 2 noclehy, $5 \%$ na 3 až 7 noclehů a $1 \%$ respondentů přenocovalo v Jihlavě více než osmkrát (graf 3 ).

Graf 3: Délka pobytu mimojihlavských návštěvníků Zoo Jihlava ve městě Jihlavě Graph 3: Duration of stay in Jihlava by non-residential visitors of the Zoo Jihlava

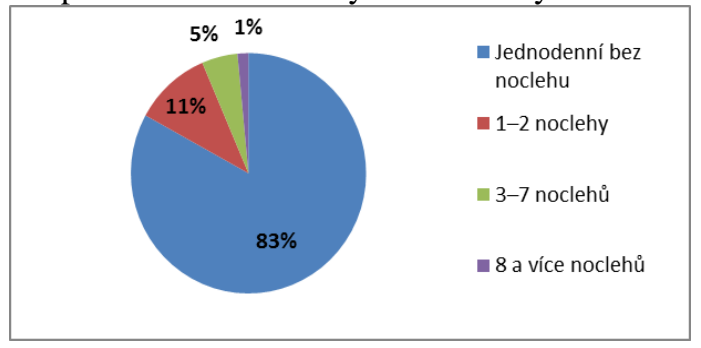


Při analýze výsledků po jednotlivých měsících je patrné, že o prázdninách (v červenci) se výrazně zvyšuje podíl návštěvníků zoo, kteří v Jihlavě tráví více než 3 noci (nejsou zde pouze o víkendu) - v květnu to byla $3 \%$ respondentů, $\mathrm{v}$ červnu $1 \%$, ale $\mathrm{v}$ červenci to byla téměr pětina dotázaných $(16 \%)$. V cestovním ruchu platí, že při rostoucí délce pobytu v destinaci rostou požadavky návštěvníků na doplňkové služby, tedy i na nabídku a kvalitu volnočasových služeb pro rodiny $\mathrm{s}$ dětmi. Je tedy téměř jisté, že př́ípadné rozšíření nabídky služeb pro rodiny $\mathrm{s}$ dětmi by touto skupinou respondentů bylo vnímáno pozitivně a mohlo by je motivovat k prodloužení svého pobytu $\mathrm{v}$ Jihlavě.

Z 204 dotázaných mimojihlavských návštěvníků Zoologické zahrady Jihlava, kteři ve městě $\mathrm{s}$ dětmi přenocovali, jich téměř $60 \%$ přenocovalo u známých, př́ibuzných nebo ve vlastní chatě/chalupě, tzn., že nevyužili komerčních ubytovacích služeb (graf 4). Druhou nejčastěji volenou variantou ubytování byl pronajatý apartmán/chata, tuto možnost zvolilo $21 \%$ přenocujících respondentů. Zařízení hromadného ubytování (hotel, penzion) dohromady zvolilo $14 \%$ přenocujících respondentů.

Graf 4: Zvolený typ ubytování v Jihlavě

Graph 4: Selected accommodation type in Jihlava

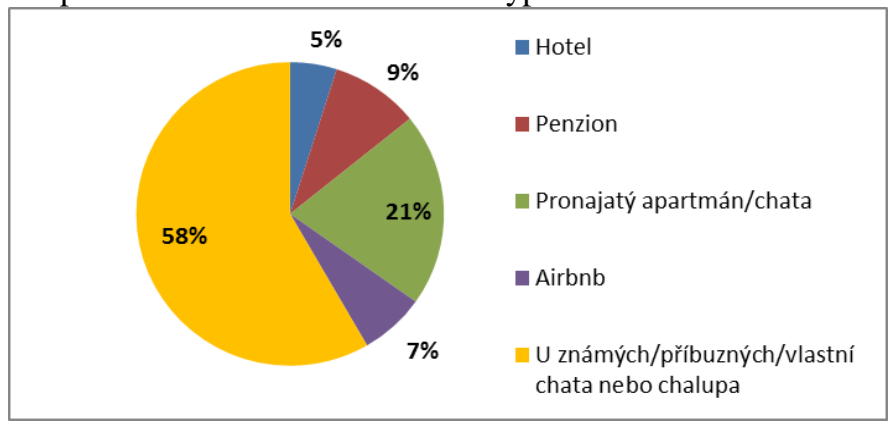

Více než tři čtvrtiny rodin $\mathrm{s}$ dětmi $(84 \%$ respondentů) se během zkoumaného pobytu $\mathrm{v}$ Jihlavě stravovaly ve veřejných stravovacích zařízeních. Necelá pětina dotázaných služeb veřejných stravovacích zařízení nevyužila. Jako nejčastější důvod, proč se rodiny $\mathrm{s}$ dětmi nestravují ve veřejných stravovacích zařízeních, bylo uváděno, že mají s sebou vlastní jídlo (11\% respondentů), případně že se stravují u známých nebo doma (4\%).

Necelá polovina dotázaných uvedla ve výzkumu konkrétní restauraci, nebo kavárnu, kterou v Jihlavě navštívili, nebo měli v plánu navštívit. Nejčastěji bylo uváděno občerstvení v zoo, a to u $17 \%$ respondentů. Na jednu stranu je pro služby v Zoologické zahradě Jihlava pozitivním zjištěním, že nejvíce rodin s dětmi se stravovalo $\mathrm{v}$ jejich areálu, na stranu druhou to byla ale pouze necelá pětina 
z celkového počtu respondentů, což s velkou pravděpodobností znamená, že nabídka stravovacích služeb $\mathrm{v}$ zoologické zahradě není vnímána jako dostatečně atraktivní, i přesto, že rodiny stráví v zoo značnou část dne. Nabízí se zde tedy prostor pro inovace služeb do budoucna.

Pro tři čtvrtiny rodin s dětmi, které navštíví Zoologickou zahradu Jihlava, je návštěva zoo hlavním důvodem návštěvy Jihlavy. Toto zjištění potvrzuje, jak významným turistickým cílem je samotná zoologická zahrada. Z těchto respondentů jich třetina ve městě realizuje i jiné aktivity, pro dvě třetiny respondentů byla ale návštěva zoo jedinou plánovanou aktivitou $\mathrm{v}$ Jihlavě. Současně z výsledků výzkumu vyplývá, že Zoo Jihlava není hlavním důvodem návštěvy města především pro ty respondenty, kteří $v$ Jihlavě alespoň jednou přenocují.

527 dotázaných (44\%) během svého pobytu v Jihlavě realizovalo kromě návštěvy zoologické zahrady i jiné aktivity. Nejčastěji se jednalo o prohlídku centra města. Necelá polovina rodin s dětmi, které kromě návštěvy zoo realizovaly v Jihlavě i jiné aktivity, byla na návštěvě obchodního centra City Parku. Pětina z těchto aktivnějších dotázaných navštívila také Vodní ráj Jihlava, necelá pětina potom jinou kulturní či sportovní akci nebo kulturně-historické pamětihodnosti města (především jihlavské podzemí).

\section{Nákupní chování respondentů v př́ípadě rozšíření nabídky služeb pro rodiny s dětmi}

Tato kapitola shrnuje zjištěné názory dospělých mimojihlavských návštěvníků Zoologické zahrady Jihlava na jejich budoucí nákupní chování $\mathrm{v}$ prŕípadě, že dojde k rozšíření nabídky služeb pro rodiny s dětmi v zoo, nebo v její blízkosti.

Nejdřive byl zkoumán zájem respondentů o účast na aktivitách pro rodiny s dětmi v bezprostřední blízkosti zoo. Naprostá většina dotázaných $(89 \%)$ by o účast na takovýchto aktivitách měla zájem, nadpoloviční většina respondentů dokonce uvedla, že by se určitě zúčastnili.

V návaznosti na předchozí dotaz bylo dále zjišt’ováno, o jaké aktivity by rodiny s dětmi v blízkosti zoo měly zájem. Na tuto otázku bylo možno uvést více odpovědí, celkem bylo od respondentů získáno 5135 odpovědí, které prezentuje graf 5.

Z uvedených odpovědí vyplývá, že nejatraktivnější aktivitou respondenti shledávají návštěvu akvária. Výhodou této atraktivity by po jejím vybudování jednoznačně byla možnost celoročního provozu, na druhou stranu je potřeba provést ekonomickou rozvahu realizačních a následně provozních nákladů této služby a také zhodnotit konkurenci podobného typu, která už v České republice existuje. Sportovní a pohybové aktivity, které vybrala téměř polovina respondentů, by byly značně limitovány pouze letním sezónním provozem. Je ale samozřejmě 
možné tuto skutečnost částečně eliminovat, např. vybudováním indoorové lezecké stěny. Za pozornost také stojí zájem přibližně $40 \%$ respondentů o využití areálu letního kina, který těsně přiléhá $\mathrm{k}$ zoologické zahradě. Program pro rodiny s dětmi by tam jistě bylo možné zrealizovat, pouze by bylo nutné sladit tyto akce $\mathrm{s}$ převážně večerním využitím tohoto prostoru. Nabízí se např. možnost poskytování dětských animačních programů, které by bylo možné propojit i s vlastní návštěvou zoo.

Graf 5: Preferované aktivity pro rodiny s dětmi v blízkosti Zoo Jihlava Graph 5: Preferred activities for families with children near the Jihlava Zoo

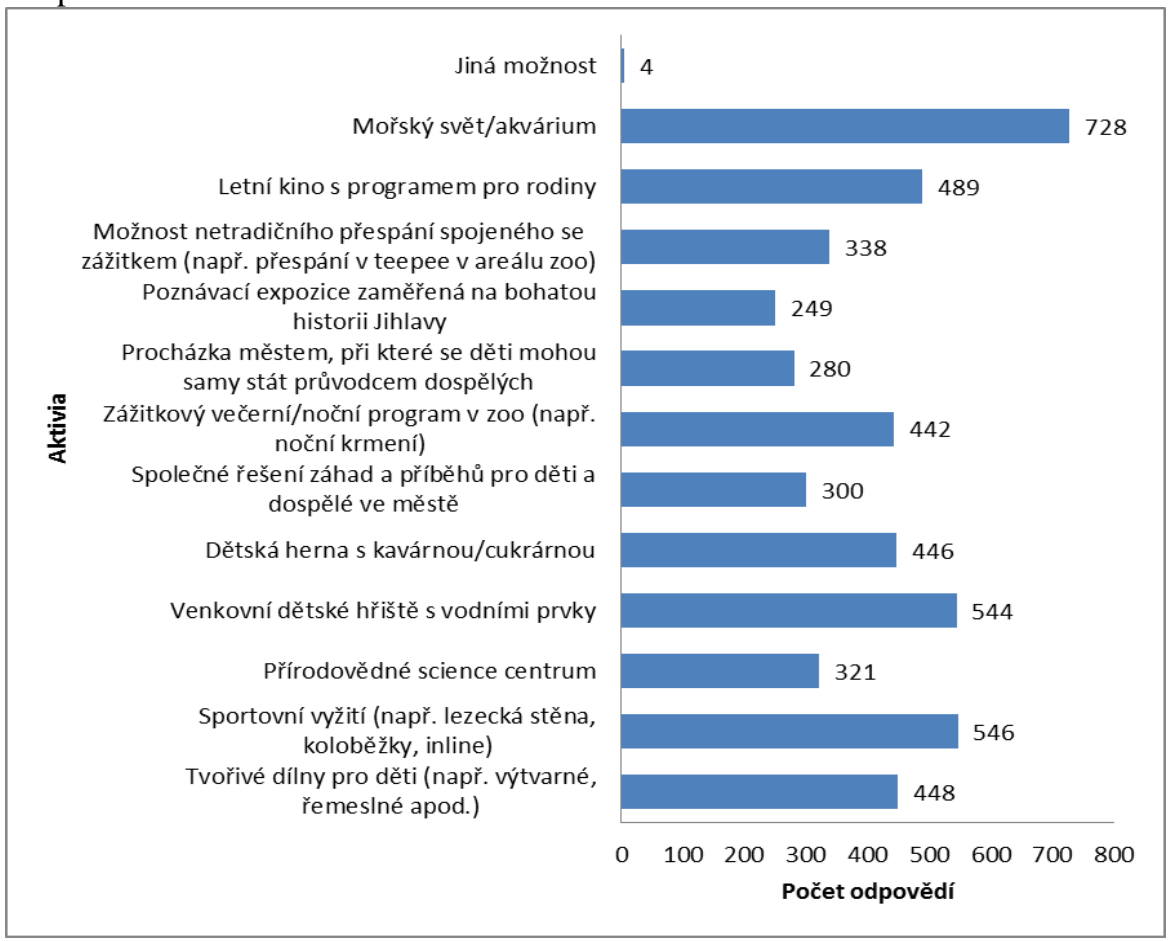

Dalším důležitým poznatkem je, že za volnočasové aktivity navazující na návštěvu zoo (tzn. ne např. za stravování) by nadpoloviční většina dotazovaných byla ochotna utratit částku 101 - $300 \mathrm{Kč} \mathrm{na} \mathrm{osobu} \mathrm{(cca} \mathrm{3,8} \mathrm{-} \mathrm{11,5} \mathrm{EUR).} \mathrm{Nad}$ $500 \mathrm{Kč} \mathrm{na} \mathrm{osobu} \mathrm{(cca} 19$ EUR) by bylo ochotno zaplatit pouze $2 \%$ dotazovaných a více než pětina by byla ochotna zaplatit maximálně 100 Kč (cca 3,8 EUR).

Č́stku 301 - 500 Kč (cca 11,5 - 19 EUR) by bylo ochotno za další volnočasové aktivity navazující na návštěvu Zoo Jihlava utratit na osobu v květnu $9 \%$ a v červnu $8 \%$ respondentů, v červenci to ovšem byla více než pětina $\mathrm{v}$ tomto 
měsíci dotázaných (23\%). I když souhrnný výsledek za celé sledované období výzkumu je u intervalu 301 - 500 Kč (cca 11,5 - 19 EUR) $13 \%$ respondentů, nabízí se zde úvaha nad možností zavedení sezónních a mimosezónních cen za poskytované služby.

V souvislosti se snahou o prodloužení pobytu ve městě byli mimojihlavští návštěvníci dotazováni na aspekty, které jsou pro ně rozhodující v př́ípadě hledání vhodného ubytování. Respondenti měli možnost výběru až dvou možností, celkem bylo $\mathrm{k}$ tomuto tématu získáno 2085 odpovědí.

Graf 6: Aspekty ovlivňující výběr ubytování mimojihlavských návštěvníků Zoo Jihlava

Graph 6: Aspects influencing choosing an accommodation of non-residential visitors of Zoo Jihlava

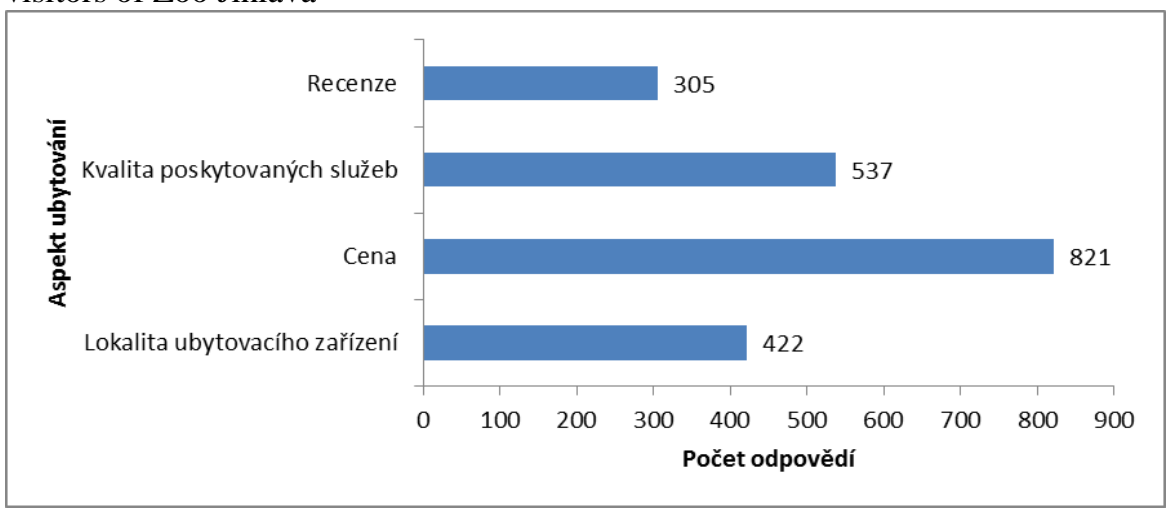

Jak je patrné z grafu 6, nejdůležitějším aspektem pro $68 \%$ dotázaných je cena ubytování, což je v souladu se zjištěnou strukturou zvoleného typu ubytování v Jihlavě, kde převládá nekomerční ubytování, napřs. u př́ibuzných (viz graf 4).

Dotazovaní měli také možnost vyjádřit se k horní hranici ceny za ubytování, kterou by byli ochotni zaplatit. Necelá polovina dotázaných mimojihlavských návštěvníků zoo definovala jako horní hranici ceny za 1 nocleh bez snídaně pro 2 dospělé osoby + max. 2 děti částku 1500 Kč, více by nebyli za ubytování v Jihlavě ochotni a schopni zaplatit. Čtvrtina respondentů by nezaplatila ani částku nad $1000 \mathrm{Kč}$, další čtvrtina by však byla ochotná zaplatit až $2000 \mathrm{Kč}$. Nad 3000 Kč by za ubytování zaplatilo dohromady pouze 9 z 1200 dotázaných, z toho 3 by byli ochotni zaplatit i více než $3501 \mathrm{Kč}$.

Ze zjištěných informací tedy vyplývá, že pokud cena za ubytování za noc bude pro rodinu s dětmi vyšší než 1000 Kč, pak by tuto cenu byly ochotny zaplatit tři čtvrtiny mimojihlavských návštěvníků zoo, bude-li vyšší než 1500 Kč, pak už by k platbě byla ochotna pouze prribližně třetina (34 \%) respondentů. 


\section{Vyhodnocení výsledků}

Na základě výsledků výzkumu realizovaného mezi návštěvníky Zoo Jihlava lze prohlásit, že typickým dospělým mimojihlavským návštěvníkem zoologické zahrady, který s sebou přivedl do zoo děti, je:

- Žena s ukončeným minimálně středoškolským vzděláním, které je přibližně mezi třiceti až padesáti lety.

- Tato žena s sebou do zoo přivede nejčastěji dvě vlastní děti, méně často jedno vlastní dítě. Nadpoloviční většina doprovázených dětí je předškolního věku (54 \%) a téměř polovina dětí je ve věku, kdy navštěvují základní školu (6 - 15 let).

- Žena s dětmi bydlí v České republice a do zoologické zahrady přijeli s více než $50 \%$ pravděpodobností z Kraje Vysočina. Pokud přijeli z jiných krajů našeho státu, pak s největší pravděpodobností z krajů přímo sousedících s Krajem Vysočina.

- Návštěvník není v Zoologické zahradě Jihlava poprvé, a pokud bydlí v Kraji Vysočina, tak se s velkou pravděpodobností vrací do zoo opakovaně.

- Typický návštěvník $\mathrm{s}$ dětmi má $\mathrm{v}$ plánu se do zoo $\mathrm{v}$ průběhu následujících 12 měsíců znovu vrátit, a to $\mathrm{s} 62 \%$ pravděpodobností.

- Osm z deseti rodin s dětmi přijelo do Jihlavy pouze na jednodenní výlet a nemají v úmyslu zde přenocovat.

- Pokud rodina s dětmi, která navštívila zoologickou zahradu, v Jihlavě přenocuje, s $60 \%$ pravděpodobností nevyužije komerčních ubytovacích služeb, ale přenocuje u známých, prŕbuzných, nebo ve vlastní chatě/chalupě.

- Typický návštěvník zoo se s rodinou během svého pobytu v Jihlavě stravuje ve veřejných stravovacích zařízeních (84\% respondentů), nejčastěji využije občerstvení v zoologické zahradě nebo v City Parku.

- Návštěva zoologické zahrady je hlavním důvodem návštěvy města Jihlavy pro tři čtvrtiny rodin $\mathrm{s}$ dětmi. $Z$ těchto respondentů jich třetina ve městě realizuje i jiné aktivity než návštěvu zoo (procházku centem města, návštěvu City Parku...).

Zoologickou zahradu Jihlava s dětmi navštěvují více než dvakrát častěji ženy než muži. Této struktuře mimojihlavských návštěvníků by měla být přizpůsobena také nabídka doplňkových služeb v zoologické zahradě.

Podle svého věku patří ženy navštěvující s dětmi zoo do ekonomicky aktivní skupiny obyvatelstva, obvykle se jejich věk pohybuje mezi necelými třiceti až padesáti lety věku.

Výzkum potvrdil vyšší míru vzdělanosti dospělých, kteří vodí své děti do zoologické zahrady. S rostoucí vzdělaností účastníků cestovního ruchu roste obvykle jejich náročnost na kvalitu poskytovaných služeb a současně pro opakovanost návštěv vyžadují nové impulzy, např. v podobě inovace služeb. 
Zoo Jihlava je atraktivním místem trávení času především pro rodiny s dětmi do pěti let. Velice pozitivní je pro zoo skutečnost, že pětina respondentů $\mathrm{z}$ řad mimojihlavských rodin s dětmi přichází opakovaně. Na druhou stranu to ale opětovně ukazuje na nutnost vytváření produktových inovací, napřr. různými tematickými akcemi, aby respondenti měli důvod k další a další návštěvě zoo.

Při zjištování zájmu o opakovanou návštěvu zoologické zahrady v následujících 12 měsících ode dne dotazování vyšlo najevo, že téměř $40 \%$ $\mathrm{z}$ celkového množství dotázaných rodin $\mathrm{s}$ dětmi s tím nepočítá, nebo o tom zatím není rozhodnuta. Tento výsledek pro zoo není př́liš pozitivní a bylo by vhodné zjistit důvody těchto postojů respondentů, např. navazujícím výzkumem. Je možné se domnívat, že informace o tematických akcích realizovaných zoologickou zahradou nejsou mezi cílový segment rodin s dětmi dostatečně efektivně širreny (z hlediska způsobu nebo času). Důvodem může být i výše ceny vstupného, kterou si některé rodiny nemohou dovolit př́liš často uhradit ze svých rozpočtů nebo také nespokojenost $\mathrm{s}$ kvalitou a rozsahem poskytovaných služeb. Důvodem nezájmu o brzké opakování návštěvy může být také skutečnost, že rodiny s dětmi se snaží vymýšlet pestrý program pro svůj volný čas, který se neopakuje. Podnětem $\mathrm{k}$ opakované návštěvě zoo $\mathrm{v}$ prrípadě těchto návštěvníků by se mohly stát různé tematické akce, o kterých je potřeba $\mathrm{s}$ dostatečným časovým předstihem potenciální návštěvníky informovat.

Výsledek výzkumu, který dokládá nejvyšší návštěvnost z krajů, jež přímo sousedí s Krajem Vysočina, je pro marketingové aktivity Zoo Jihlava velice důležitý, nebot' ukazuje, kam cílit své propagační aktivity v budoucnu, stejně jako je pro zoo důležité poznání, že je stále potřeba cílit propagaci i do vnitřního prostředí Kraje Vysočina. Propagace by měla být cílena především na rodiče dětí předškolního a mladšího školního věku, přes léto pak může být efektivně cílená i přímo na potenciální dětské návštěvníky.

Nejvíce mimojihlavských rodin s dětmi se stravovalo v areálu Zoo Jihlava, ale byla to pouze necelá pětina $\mathrm{z}$ celkového počtu respondentů. $\mathrm{Z}$ tohoto výsledku $\mathrm{s}$ velkou pravděpodobností vyplývá, že nabídka stravovacích služeb v zoo není vnímána jako dostatečně atraktivní i přesto, že rodiny zde tráví značnou část dne. Nabízí se zde tedy prostor pro inovace stravovacích služeb do budoucna.

Nadpoloviční většina mimojihlavských respondentů (56 \%) během svého pobytu v Jihlavě neplánovala kromě návštěvy zoo žádné další aktivity. Pro efektivnější řízení rozvoje cestovního ruchu města Jihlavy by bylo vhodné, aby byly zjištěny důvody tohoto jednání respondentů, např. zda je to z časových důvodů (návštěva zoo zabere celý den), z finančních důvodů, nedostatečné atraktivnosti nabídky služeb pro rodiny s dětmi ve městě atp.

Naprostá většina dotázaných návštěvníků zoologické zahrady ( $89 \%$ ) by o účast na zajímavých aktivitách pro rodiny s dětmi měla zájem, pokud by se jednalo o aktivity v bezprostřední blízkosti Zoologické zahrady Jihlava. 
Respondenti označili jako nejlákavější tři aktivity:

- mořský svět/akvárium,

- sportovní vyžití pro rodiny s dětmi,

- venkovní dětské hřriště s vodními prvky.

Lze předpokládat, že akvárium by v letním období bylo vhodným doplňkem návštěvy zoo a mohlo by prodloužit dobu pobytu návštěvníků Jihlavy. V zimním období by pro mimojihlavské rodiny s dětmi mohlo být i samostatným důvodem k návštěvě města. Výhodou mořského světa/akvária by jednoznačně byla možnost celoročního provozu, na druhou stranu je potřeba provést ekonomickou rozvahu realizačních a následně provozních nákladů této služby a také zhodnotit konkurenci podobného typu, která už v České republice existuje. Akvárium by však šlo vhodně tematicky propojit s venkovním dětským hřištěm s vodními prvky a také s tematickou dětskou hernou s kavárnou/cukrárnou.

Za volnočasové aktivity navazující na návštěvu zoo (tzn. ne např. za stravování) by nadpoloviční většina mimojihlavských respondentů byla ochotna utratit částku 101 - 300 Kč na osobu. I když se částka do 300 Kč může na první pohled zdát nízká, vzhledem $\mathrm{k}$ tomu, že dotazování se týkalo rodin $\mathrm{s}$ dětmi, které při využití jakékoli atraktivity musí počítat s platbou vstupného pro více osob, vzhledem $\mathrm{k}$ průměrným platům v České republice a také vzhledem $\mathrm{k}$ uvažovaným aktivitám, lze tuto částku považovat za vyhovující.

Při hledání vhodného ubytování je pro mimojihlavské rodiny $\mathrm{s}$ dětmi rozhodujícím aspektem cena ubytování. Ze zjištěných informací vyplývá, že pokud cena za ubytování za noc bude pro rodinu s dětmi vyšší než 1000 Kč, pak by tuto cenu byly ochotny zaplatit tři čtvrtiny dotázaných, bude-li vyšší než 1500 Kč, pak už by k platbě byla ochotna pouze třetina respondentů. Cena za ubytování by se tedy mohla pohybovat v rozmezí $1000-1500$ Kč.

\section{Závěr}

Pochopení přání a potřeb návštěvníků umožňuje zvolení přesně cílených marketingových př́stupů a umožní vytvořit vhodné inovace $\mathrm{v}$ produktovém portfoliu, což následně zvýší počty prvních i opakovaných návštěv, prodlouží celkovou dobu pobytu návštěvníků apod. a zlepší tak návratnost investovaných prostředků díky generování vyšších celkových př́ijmů (Palatková a Zichová, 2011).

K tomuto cíli směřoval výzkum mezi návštěvníky jihlavské zoo, který zadal Magistrát statutárního města Jihlava a který realizovala Katedra cestovního ruchu VŠPJ v letních měsících roku 2018. Autoři jsou si vědomi, že skutečnost, že sběr dat neprobíhal po celý rok, ale pouze po dobu vybraných třech měsíců, je určitým limitem realizovaného výzkumu. Přesto je, vzhledem ke zvolené metodice sběru dat a $\mathrm{k}$ celkovým počtům respondentů, možné výsledky výzkumů považovat za relevantní a dostatečně vypovídající. Pro účinné řízení Zoologické zahrady Jihlava 
i cestovního ruchu ve městě Jihlava ovšem doporučujeme ve sběru a vyhodnocování dat $\mathrm{v}$ budoucnu opakovaně pokračovat tak, aby vznikly časové řady údajů o návštěvnících.

\section{Literatúra}

CARR, N. 2016. An analysis of zoo visitors' favourite and least favourite animals. In Tourism Management Perspectives. ISSN 2211-9736, 2016, vol. 20, no. 1, pp. 70-76.

CZECHTOURISM. 2018. Návštěvnost turistických cílů 2017. CzechTourism [online]. Praha, 2018 [cit. 2018-08-14]. Dostupné na internete: https://www.czechtourism.cz/getattachment/Pro-media/Tiskove-zpravy/Navste vnost-turistickych-cilu-v-CR-lakaji-historic/Czech_Tourism_nej_turisticke_cile .pdf.aspx?ext=.pdf

JAKUBÍKOVÁ, D. 2008. Strategický marketing. Praha: Grada Publishing, 2008. 267 s. ISBN 978-80-247-2690-8.

KALKA, R. - MÄßEN, A. 2003. Marketing. Praha: Grada Publishing, 2003. 128 s. ISBN 80-247-0413-7.

KNEŽEVIĆ, M. - ŽUČKO, I. - LJUŠTINA, M. 2016. Who is visiting the Zagreb zoo: Visitors' characteristics and motivation. In Sociologija i Prostor. vol. 54, no. 2, pp. 169-184.

KOTLER, P. - ARMSTRONG, G. 2001. Marketing management. 10. vyd. Praha: Grada Publishing, 2001. 864 p. ISBN 80-247-0016-6.

KOTLER, P. - BOWEN, J. - MAKENS, J. 2014. Marketing for Hospitality and tourism. Edinburg: Pearson Education Limited, 2014. 630 p.

LEE, H. S. 2015. Measurement of visitors' satisfaction with public zoos in Korea using importance - performance analysis. In Tourism Management. 2015, vol. 47 , pp. 251-260.

LUEBKE, J. - MATIASEK, J. 2013. An Exploratory Study of Zoo Visitors' Exhibit Experiences and Reactions. In Zoo biology. vol. 32, no. 4, pp. 407-416.

MASON, P. 2010. Zoo Tourism: The Need for More Research. In Journal of Sustainable Tourism. vol. 8, no. 4, pp. 333-339.

PALATKOVÁ, M. - ZICHOVÁ, J. 2011. Ekonomika turismu: turismus České republiky: vymezení a fungováni trhu turismu, přistupy $k$ hodnocení významu a vlivu turismu, charakteristika turismu České republiky. Praha: Grada, 2011. 208 s. ISBN 978-80-247-3748-5.

PHELAN, S. - BAUER, J. - LEWALTER, D. 2018. Visit motivations: development of a short scale for comparison across sites. In Museum Management and Curatorship. vol. 33, no. 1 pp. 25-41.

STANFORD, D. J. 2014. Reducing visitor car use in a protected area: A market segmentation approach to achieving behaviour change. In Journal of Sustainable Tourism. vol. 22, no. 4, pp. 666-683. 
WHITWORTH, A. W. 2012. An Investigation into the Determining Factors of Zoo Visitor Attendances in UK Zoos. In PLoS ONE. vol. 7, no. 1. ZOO JIHLAVA. 2018. ZOO Jihlava: Výroční zpráva 2017. [online]. Jihlava: Zoo Jihlava, 2018. [cit. 2018-09-20]. Dostupné na internete: https://zoojihlava.cz//zoo/uploads/2018/06/zoo_jihlava_vz_2017_lowres.pdf

\section{BUYING PREFERENCES OF TARGET SEGMENT OF VISITORS OF THE ZOO JIHLAVA}

\section{Summary}

Zoological gardens are very popular places for spending free time not only for residents, but for visitors of destinations, too. The zoo in Jihlava is one of the best zoos in the Czech Republic and at the same time, it is the most visited tourism attraction not only in the town of Jihlava, but also in the whole Vysočina Region. This article presents results of primary marketing research among 1,200 Jihlava zoo visitors - families with children who were not residents of the town. The research was held by using questionnaires among these visitors in the year 2018. The main aim of the research was to define a profile of non-residential visitors of the zoo and to describe their current, as well as possible buying behaviour.

From the research results it can be e.g. stated that the Zoo Jihlava is attracting mainly Czech families with children, from which more than a half arrived just from the Region of Vysočina, the other respondents were most often from regions bordering with the Vysočina Region (South Bohemia, Central Bohemia, South Moravia...). The zoo is visited two times more often by women with children than by men with children. With more than $80 \%$ probability, children are to the zoo accompanied by their parents, $11 \%$ of children were in the zoo with their grandparents. More than a half of all children in the Zoo Jihlava were in their pre-school years (up to 5 years of age), most of the rest ones were under 15. It is also interesting that $70 \%$ of non-residential respondents visit the zoo repeatedly, but nearly $40 \%$ of respondents did not plan to return in the next twelve months.

Eight from every ten families with children came to Jihlava only for a one day visit, they did not overnight. If they overnight, they stay with more than $60 \%$ probability at their relatives, friends, or in their own weekend house.

Nearly $90 \%$ of all respondents would be interested in another activities for families with children if these activities were located in the close neighbourhood of the Zoo Jihlava. Most attractive would be for them a sea world/aquarium, sporting activities, or outdoor playground with water features. For free time activities after visiting the zoo, more than a half of respondents would pay only $101-300 \mathrm{CZK} /$ per person. 
Understanding wishes and needs of visitors allow choosing appropriate innovations in marketing tools, or a product portfolio. These innovations can help to increase numbers of first, as well as repeated visits, or even extend total time of visitors stay - and so they help to generate higher total revenues. Our research results should be used by the municipality of the town Jihlava (owner of the zoo), but they can be used also as an example of a practical use of a marketing research.

RNDr. Mgr. Stanislava Pachrová, Ph.D.

RNDr. Eva Janoušková, Ph.D.

Ing. Alice Šedivá Neckářová, Ph.D.

Vysoká škola polytechnická Jihlava

Tolstého 16, 58601 Jihlava

E-mail: stanislava.pachrova@vspj.cz, eva.janouskova@vspj.cz, alice.sediva@vspj.cz 